\title{
2D Gravimetric Modelling of the central portion of Quadrilátero Ferrífero, Brazil
}

\author{
Araújo, J.C.S. ${ }^{1}$; Matos, C.A.; Dias, P.H.A. ${ }^{1}$
}

${ }^{1}$ Geological Survey of Brazil (SGB-CPRM)

Copyright 2021, SBGf - Sociedade Brasileira de Geofísica

This paper was prepared for presentation during the $17^{\text {th }}$ International Congress of the Brazilian Geophysical Society held in Rio de Janeiro, Brazil, 16-19 August 2021.

Contents of this paper were reviewed by the Technical Committee of the $17^{\text {th }}$ International Congress of the Brazilian Geophysical Society and do not necessarily represent any position of the SBGf, its officers or members. Electronic reproduction or storage of any part of this paper for commercial purposes without the written consent of the Brazilian Geophysical Society is prohibited.

\section{Abstract}

The Quadrilátero Ferrífero, located at the southern São Francisco craton, is one of the most important metallogenic districts in Brazil. Multiple deformational events affected this region and several studies, based mainly on structural field mapping argue about its tectonic evolution. Geophysical techniques applied to delineate subsurface can be useful for a better understanding of its tectonic framework. The present study consists of a gravimetric survey in the central portion of Quadrilátero Ferrífero, encompassing its three main geological units: the TTG basement, the Rio das Velhas greenstone belt, and the Minas Supergroup. The acquired data were processed in three gravimetric 2-D profiles and the modeling was based also on surface geological data and previous tectonic studies of the area. The geophysicalgeological profiles modeled suggest that the Rio das Velhas basin, in the Nova Lima-Caeté tectonostratigraphic block, shows distinct composition and thickness in its eastern and western regions. The eastern portion would be composed of a thin base layer with a predominance of mafic/ultramafic metavolcanic rocks and a thick top layer with metasedimentary rocks. On the other hand, the western area would have a remarkable predominance of mafic/ultramafic metavolcanic rocks belonging to a thick basal layer. For the Minas Supergroup in the Serra da Piedade region, an inverted syncline is the model that best suited the gravimetric data. The inverted flank is exposed by the Serra da Piedade and the normal flank doesn't outcrop.

\section{Introduction}

The Quadrilátero Ferrífero (QF) comprises an area of approximately $7000 \mathrm{Km} 2$ in the southeast portion of the São Francisco craton, within the central and southern regions of Minas Gerais state (Almeida, 1967; Dorr II, 1969). It contains three main lithostratigraphic units: (i) an Archean granite-gneiss complex including the exposed Belo Horizonte, Caeté, Bonfim, Bação and Santa Bárbara domes (Teixeira et al., 2000); (ii) the Rio das Velhas greenstone belt (RVGB), an Archean volcanosedimentary sequence divided into the Quebra Osso, Nova Lima and Maquiné groups (Dorr II, 1969; Zucchetti and Baltazar, 2000; Araújo et al., 2020); and (iii)
Neoarchean-Proterozoic metasedimentary sequences represented by the Minas Supergroup and the Sabará and Itacolomi groups (Dorr II, 1969).

The present study consists in the gravimetric $2 \mathrm{D}$ modeling of the Nova Lima - Caeté region. It is part of the project '2D and 3D modeling of the Rio das Velhas greenstone belt framework', inserted into the Quadrilátero Ferrífero Program of the Brazilian Geological Survey (SGBCPRM). The first stage of this project aimed the 2D modeling of geophysical-geological profiles in various sectors of the Quadrilátero Ferrífero, with a focus on the Rio das Velhas greenstone belt. The modeling used terrestrial gravimetry data, obtained by the SGB-CPRM and by the national bank of gravimetric data (BNDG), and geological and geotectonic maps from the study area. The aim of this research is to contribute to the understanding of the tectonic framework of the QF. The integrated interpretation of geologic and geophysical data provides important insights into the behavior of the main geologic units in depth, following the approach already used successfully in other greenstone belts (Ranganai, 2012; Ramotoroko et al., 2016).

\section{Method}

The gravimetric data from SGB-CPRM were acquired with the CG5 Autograv Gravity Meter differential gravimeter (Scintrex) and a pair of differential GPS, model Hiper SR (Topcon). One GPS were used as base station and its distance from the mobile GPS did not exceed $40 \mathrm{Km}$. A total of 212 stations, with spacing between $250 \mathrm{~m}$ and $2 \mathrm{Km}$, were acquired along major highways and local roads in the Nova Lima-Caeté area, in three profiles that crosscut important geologic structures (Fig. 1). In addition, the data provided by the BNDG were used.

For GPS data processing, the softwares Magnet Tools, MAPGEO2010 and MAPGEO2015 were used. The gravimetric data processing, done in the Oasis Montaj (Geosoft) software, includes the following corrections: tidal, sensor height, drift, latitude, absolute gravity, normal gravity, Free Air, Bouguer and Terrain. After that stage, the Bouguer Anomaly, Regional Gravity and Residual Gravity Maps were elaborated.

The results from the Residual Bouguer Anomaly were utilized for the 2D gravimetric modeling of three geophysical-geological profiles. Due to the winding roads, the stations were projected in straight profiles. The direct modeling was performed using the software GMSYS-2D, a toolkit within the Geosoft Oasis montaj platform, which calculates the predicted anomaly following Talwani and Heirtzler (1964) and Talwani et al. (1959). The layers, with a defined density, are drawn and adjusted to better suit the observed data. The values used were based on the average density of rocks present in each layer. Data 
from drill core samples from the Nova Lima-Caeté region, afforded by the company Anglo Gold Ashanti, provided additional information that helped in the modeling process and to define densities.

\section{Results}

The Nova Lima-Caeté area comprises three gravity profiles, designated Caeté, Nova Lima and Caeté-Gongo Soco (Fig. 1). The profiles crosscut three important geologic units: (i) the granitic-gnaissic basement represented by the Belo Horizonte and Caeté Complex and the General Carneiro granitoid; (ii) the RVGB metavolcanosedimentary sequence; and (iii) metasedimenary rocks from the Minas Supergroup and Sabará Group.

For the modeling, a simplification of the geology was made, grouping units containing rocks with similar densities. The Nova Lima Group was divided into three layers containing predominantly: mafic/ultramafic metavolcanic rocks; mafic metavolcanic rocks, chemical and clastic metasedimentary rocks; clastic metasedimentary rocks. The Minas Supergroup was also divided in three units: the banded iron formation (BIF) layer from the Cauê Formation and metasedimentary rocks below and above it.

* Caeté profile: It is approximately $21 \mathrm{Km}$ long, with WNW-ESE direction, and 114 gravimetric stations, acquired along the BR-262 highway, in the vicinities of Sabará and Caeté cities (Fig. 1).

The data for this profile (Fig. 2Al) shows the biggest Bouguer anomaly over the Minas Supergroup, with

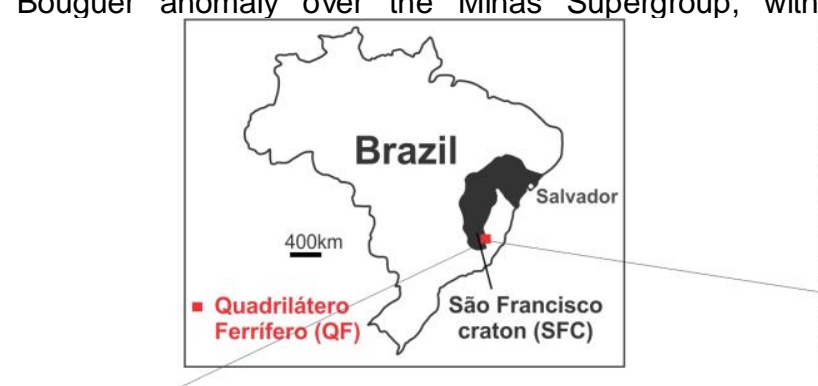

intensity of approximately $+6 \mathrm{mGal}$. Both Belo Horizonte and Caeté Complex are characterized by low Bouguer signature, while the General Carneiro granitoid present intermediate values. The RVGB is mainly marked by a low Bouguer signature although where the maficultramafic metavolcanic rocks outcrop there is a Bouguer anomaly of approximately +2 mGal.

* Nova Lima profile: It is located near Belo Horizonte and Nova Lima cities, with about $30 \mathrm{Km}$ in length and WNWESE direction. The 46 stations were collected along the MG-030 road (Fig. 1). ,

The Belo Horizonte Complex outcrops at the beginning of this profile (Fig. $2 \mathrm{BI}$ ) and it is characterized by a low Bouguer signature. The Bouguer anomaly gradually increases over the Minas Supergroup and reaches the higher values over the RVGB (+ $15 \mathrm{mGal})$.

* Caeté-Gongo Soco profile: This $26 \mathrm{Km}$ long profile, with WSW-ENE direction, has 52 stations acquired along the AMG-150 road, from Nova Lima to Raposos, and a secondary road from Raposos to Barão de Cocais (Fig. 1).

The mafic/ultramafic metavolcanic rocks from the Nova Lima Group that outcrop in the beginning of this profile (Fig. $2 \mathrm{Cl}$ ) are related with a Bouguer amplitude signature of approximately $+12 \mathrm{mGal}$. The Bouguer anomaly gradually decreases towards the metasedimentary and mafic/ultramafic metavolcanic rocks from the Nova Lima that outcrops in the middle of the profile (between +12 $m$ Gal and -5 mGal). Finally, the Caeté Complex present a low Bouguer signature.

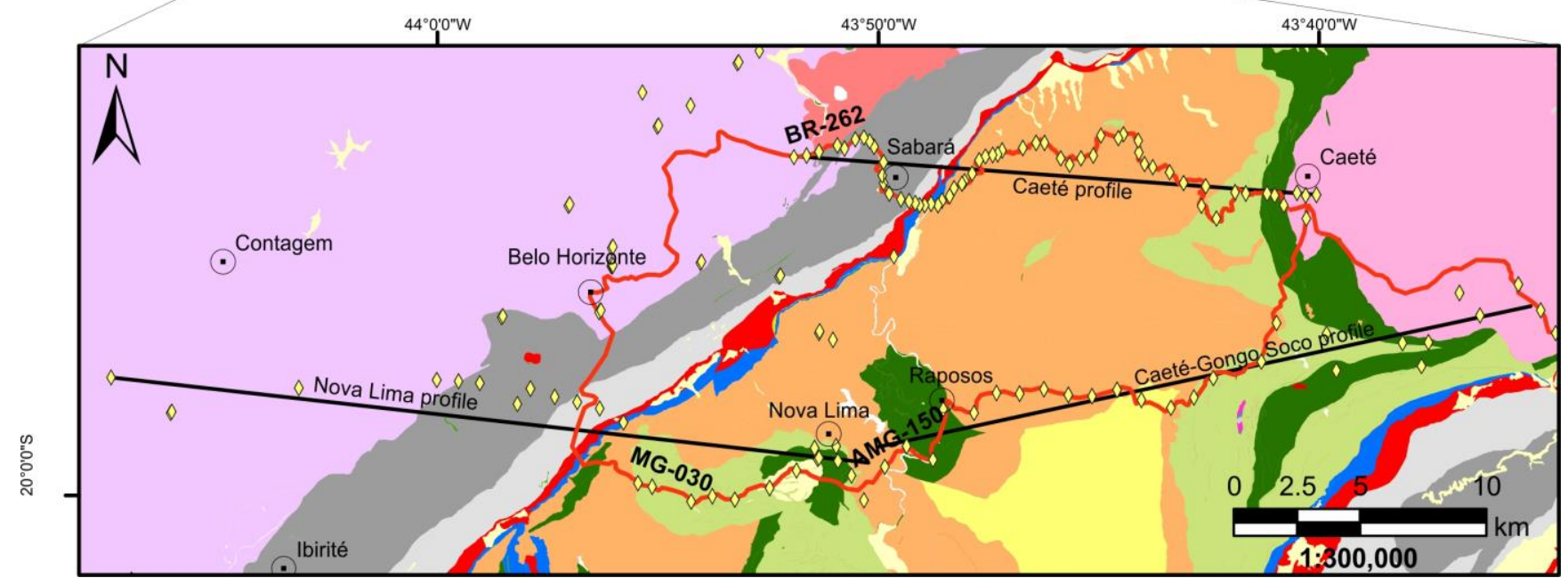

Fig. 1 - Location of the three gravimetric profiles in a simplified geological map, modified from Silva et al. (2020). 


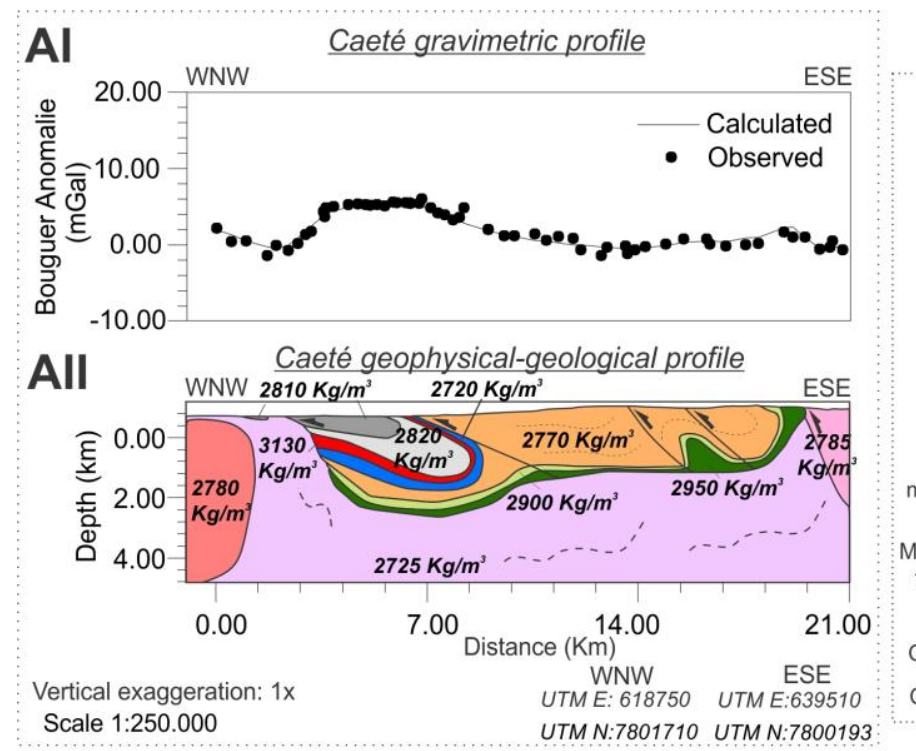

Geophysical-geological units
modeled

Diverse metasedimentary rocks $\left(2810 \mathrm{Kg} / \mathrm{m}^{3}\right)$

Dolomites and quartzites from Minas Sg. $\left(2800-2820 \mathrm{Kg} / \mathrm{m}^{3}\right)$ BIF $\left(3130 \mathrm{Kg} / \mathrm{m}^{3}\right)$

Quartzites, metaconglomerates and metapelites from Minas Sg. $\left(2720 \mathrm{Kg} / \mathrm{m}^{3}\right)$

Metasedimentary rocks from Nova Lima Gr. $\left(2770 \mathrm{Kg} / \mathrm{m}^{3}\right)$ Mafic metavolcanic and metasedimentary rocks from Nova $\bigcirc$ Morro Vermelho Fm. Lima Gr. $\left(2900 \mathrm{Kg} / \mathrm{m}^{3}\right)$

Mafic-ultramafic metavolcanic rocks from NovaLima Gr. $\left(2930 \mathrm{Kg} / \mathrm{m}^{3}\right)$ Granitoid $\left(2800 \mathrm{Kg} / \mathrm{m}^{3}\right)$

Orthogneiss $1\left(2725-2730 \mathrm{Kg} / \mathrm{m}^{3}\right)$

Orthogneiss2 $\left(2720-2785 \mathrm{Kg} / \mathrm{m}^{3}\right)$

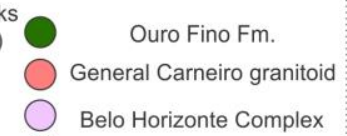
Cercadinho Fm. (Piracicaba Gr.) and Gandarela Fm. (Itabira Gr.)

- Cauê Fm. (Itabira Gr.) Batatal and Moeda Fms. (Caraça Gr.)

Ribeirão do Brumado and Mestre Caetano Fms.

Ouro Fino Fm

Belo Horizonte Complex Caeté Complex
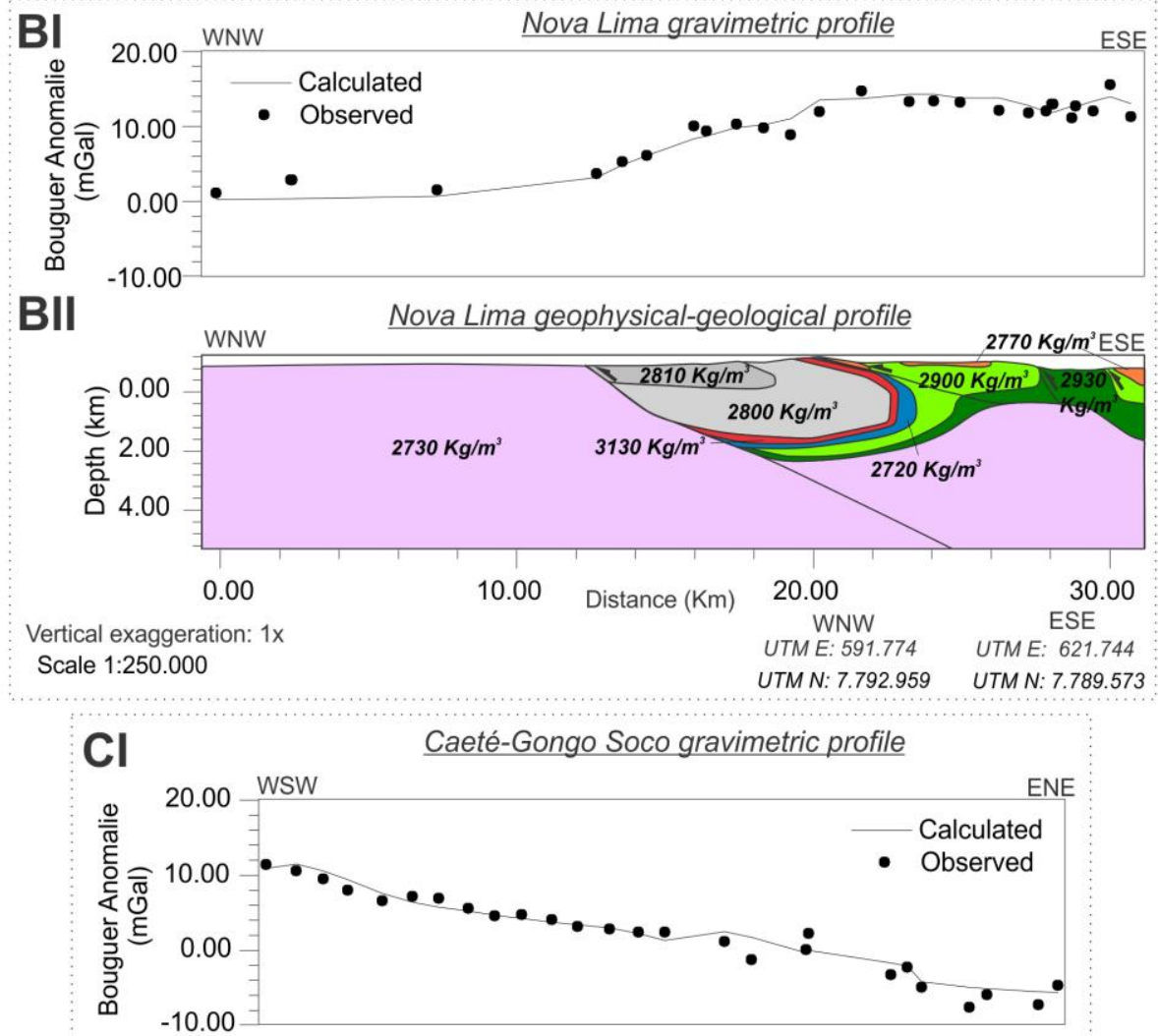

CII

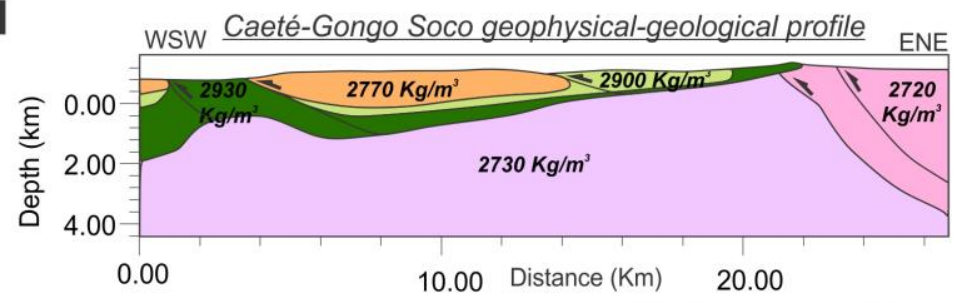

Vertical exaggeration: $1 \mathrm{x}$ $\begin{array}{cc}\text { WSW } & \text { ENE } \\ \text { UTM E: 622.256 } & \text { UTM E: 648.344 } \\ \text { UTM N: } 7.790 .209 & \text { UTM N: } 7.795 .875\end{array}$ Scale 1:250.000 
Fig. 2 - The gravimetric modelling for the (A) Caeté, (B) Nova Lima and (C) Caeté-Gongo Soco profiles, respectively. Ai, Bi and $\mathrm{Ci}$ show the gravimetric data and the calculated curve based on the geophysical-geological profiles modeled in Aii, Bii and Cii. The legend shows the geophysical-geological units modeled and their correspondent geologic units, as well as the densities used.

\section{Discussion}

The 2D modeling of these profiles, using the gravimetric and geological data available for the area resulted in the elaboration of deep geophysical-geological profiles (around $6 \mathrm{~km}$ ) that are presented in the Fig. 2. The densities used in each geological unit are also available in these figures. The three geophysical-geological profiles that were modeled in this work present great adherence with the gravimetric data.

According to the suggested model, the Nova Lima Group has distinct characteristics, in terms of composition and thickness, in different regions of the Nova Lima-Caeté block. In the northwest portion, represented by the Caeté profile (Fig. 2All), the layer composed mainly by metasedimentary rocks is much thicker than the layers where mafic/ultramafic metavolcanic rocks are predominant, and the thickess of the package reaches almost $4 \mathrm{~km}$. In the central area, better illustrated by the Caeté-Gongo Soco profile (Fig. $2 \mathrm{ClI}$ ), there is a more balanced proportion between metasedimentary and metavolcanic rocks, due to a decrease in the thickness of the layer rich in metasedimentary rocks. In this area, the thickness of the whole package reaches a maximum of $2,5 \mathrm{~km}$ and decreases gradually towards the east. Finally, on the western side of the block, there is a predominance of the basal units of the Nova Lima Group, composed mainly by mafic/ultramafic metavolcanic rocks, reaching up to $2,5 \mathrm{Km}$, as suggested by the Nova Lima profile (Fig. 2BII).

The model also suggests the presence of tight folds that locally can increase the apparent thickness of the basal layers (Fig. 2All). These tight to isoclinal folds are a common feature in the GBRV due to the multiple events deformation the area was exposed (Zucchetti and Baltazar, 2000; Baltazar and Zucchetti, 2007; Baltazar and Lobato, 2020). They can also be related to the restricted exposure of mafic/intermediate metavolcanic rocks in the Cuiabá and Lamego mines, which are surrounded by an thick package of metasedimentary rocks.

The Caeté and Nova Lima profiles crosscut the Serra da Piedade in different points and the gravimetric signature over the Minas Supergroup is quite different between them (Figs. 2Al and 2BI), affected by the adjacent rocks of the Rio das Velhas Supergroup. In the Caeté profile, a big Bouguer anomaly amplitude occurs over the Minas Supergroup (Figs. 2Al and 2All), that is in contact with predominantly metasedimentary rocks from the RVGB. In the Nova Lima profile, on the other hand, the Minas Supergroup is in contact with thick and dense mafic/ultramafic layers from the RVGB. As consequence, the higher Bouguer anomaly intensity in this profile is over the Rio das Velhas Supergroup (Figs. 2BI and 2BII).

Serra da Piedade is the extreme NE of the Serra do Curral. Its geologic architecture is not a consensus.
Pomerene (1964) interpreted the Serra do Curral as an overturned southeastern limb of a truncated syncline and the normal flank of this structure outcrops in its northeast extremitie, named Piedade Synclinal by Alves (1961). Alkmim and Marshak (1998) understood this structure as an anticlinal with its adjacent synclinal. Endo et al (2005, 2019) suggest that the Serra do Curral represent the inverted flank of an allochthonous recumbent fold (Curral Nappe) with a north tectonic transport. The Rio das Velhas Supergroup would represent the core of this fold.

In the present work, three different configurations were modeled for the Serra da Piedade structure, aiming to test the diverse proposal present in the literature: (i) a homocline representing the inverted flank of a northwestverging anticline with the RVGB in its core (Fig. $3 \mathrm{~A}$ ); (ii) the inverted flank of a synforme which normal flank is no longer preserved (Fig. 3B); (iii) a complete synforme structure, but with the normal flank not exposed (Fig. 3C).

The model (iii) is the only one that fits well with the measured data (Fig. 3C). The strong Bouguer anomaly presented in the Caeté profile coincides with the region where the BIF of the Cauê Formation outcrops and extends to NW until the Sabará Group. For the model to have good adherence to this anomaly it is necessary the preservation in subsurface of the normal flank of the syncline. Additionally, the model suggests that, in the region of the Caeté profile, the dense BIF layer of the Cauê Formation in the normal flank would be at approximately $600 \mathrm{~m}$ depth and would be thicker $(\sim 400 \mathrm{~m})$ than in the inverted flank. In contrast, in the Nova Lima profile, the model suggests that the Cauê layer is not very thick $(\sim 100 \mathrm{~m})$ throughout the structure and it is more than $2 \mathrm{~km}$ deep on its normal flank.

Only with gravimetric data it is not possible to define whether the RVGB occur at the base of the Minas Supergroup. The presence or absence of this layer below the Serra da Piedade syncline does not significantly impact the gravimetric calculated curve, due to the great depth and small thickness. However, the proposed model kept an interpretative RVGB layer below the Minas Supergroup because a small sequence of this greenstone belt is mapped north of this range. Thus, the total depth of the Serra da Piedade syncline, encompassing these two units, was modeled up to $3300 \mathrm{~m}$.

\section{Conclusions}

The gravimetry is a very useful method to investigate the geometry and depth of the geological structures (Ranganai, 2012; Ramotoroko et al., 2016). The 2D modeling, product of this stage of the project, provided a better understanding of the subsurface configuration of the central portion of the Quadrilátero Ferrífero, an important metallogenic province. 

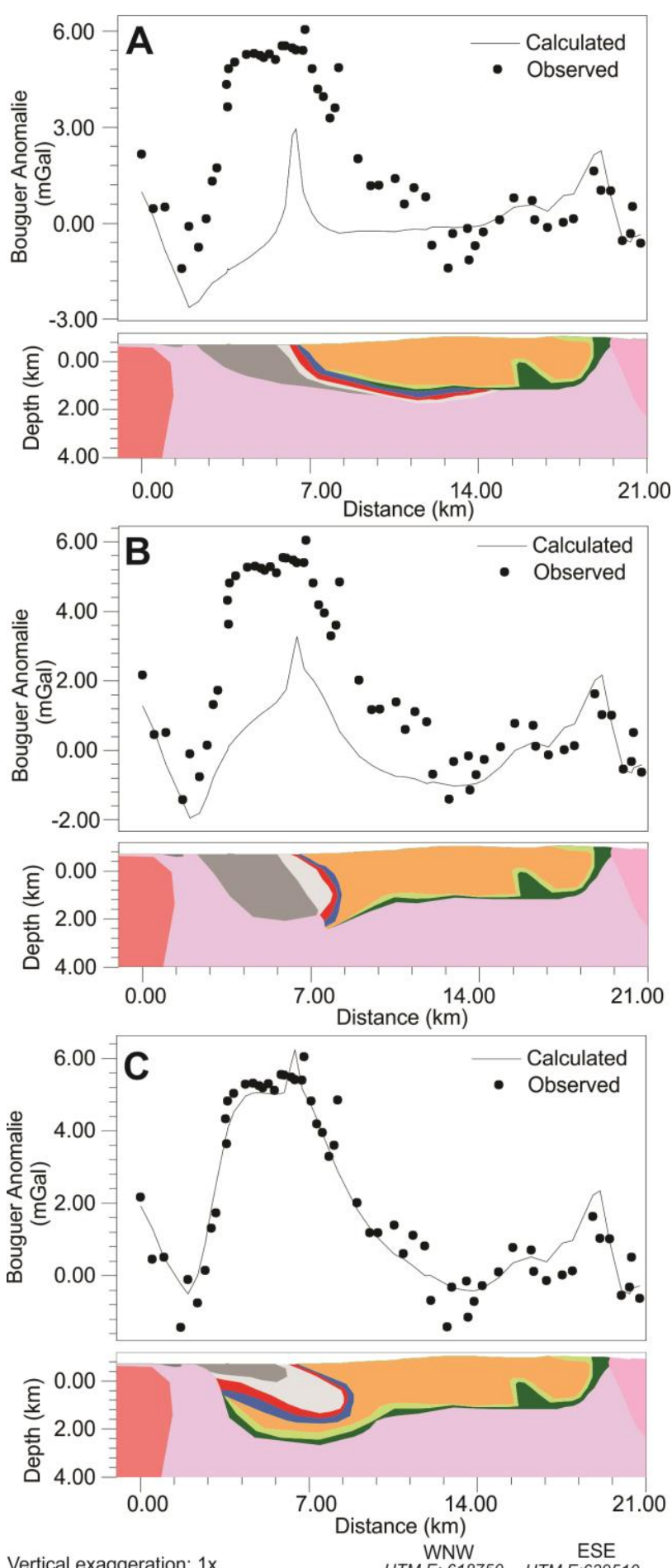

Vertical exaggeration: $1 \mathrm{x}$ Scale 1:250.000

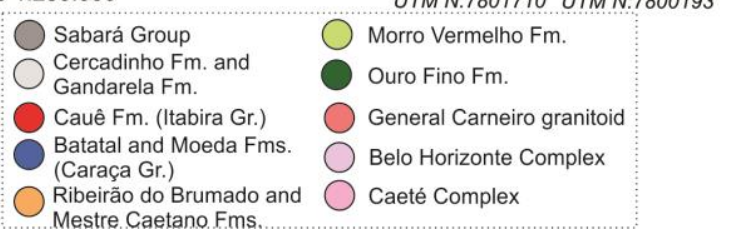

Fig. 3 - Different configurations modeled for the Minas Supergroup in the Serra da Piedade: (A) a homocline representing the inverted flank of a northwest-verging anticline with the RVGB in its core; $(B)$ the inverted flank of a synforme which normal flank is no longer preserved; (iii) a complete synforme structure, but with the normal flank not exposed.

The Caeté, Nova Lima and Caeté-Gongo Soco profiles give valuable information about the depth of the Minas and Rio das Velhas basins. The gravimetric data suggest that the eastern area of the Rio das Velhas Supergroup, close to Caeté city has a predominance of metasedimentary rocks and a thin base composed predominantly by mafic/ultramafic metavolcanic rocks. In the western region, next to Nova Lima, there would be a predominance of a thick mafic/ultramafic package. Regarding the Minas Supergroup, the only configuration that fits well with the measured data is an inverted syncline. The Serra da Piedade exposes the inverted flank while the normal flank doesn't outcrop. However, the model suggests the presence of a thick layer of BIF at approximately $600 \mathrm{~m}$ depth related to the normal flank.

\section{Acknowledgments}

This expanded abstract presents partial results of the SGB project ' $2 \mathrm{D}$ and $3 \mathrm{D}$ modeling of the Rio das Velhas greenstone belt framework'. We thank the entire team involved in this project, from acquisition to data processing. We also appreciate the data afforded by the company Anglo Gold Ashanti.

\section{References}

Alkmim F.F., Marshak S. 1998. Transamazonian orogeny in the Southern Sao Francisco craton region, Minas Gerais, Brazil: evidence for Paleoproterozoic collision and collapse in the Quadrilátero Ferrifero. Precambrian Research, 90(1-2), 29-58.

Almeida F.F.M. 1967. Origem e evolucao da plataforma brasileira. Departamento Nacional da Producao Mineral Divisao de Geologia e Mineralogia 241, 36.

Alves B.P. 1961. Sumário sobre estratigrafia e estrutura das quadrículas de Caeté e Serra da Piedade. Publicação da Sociedade de Intercâmbio Cultural e Estudos Geológicos, 1, 257-260. Ouro Preto: SICEG.

Araújo J.C.S., Ferreira R.C.F., Freitas F.M, Magalhães, J.R. 2020. The Archean Rio das Velhas greenstone belt revisited: new insights into the stratigraphy. Journal of the Geological Survey of Brazil, 3(3), 113-149.

Baltazar O.F., Zucchetti M. 2007. Lithofacies associations and structural evolution of the Archean Rio das Velhas greenstone belt, Quadrilátero Ferrífero, Brazil: A review of the setting of gold deposits. Ore Geology Reviews, 32(34), 471-499.

Baltazar O.F., Lobato M.L. 2020. Structural Evolution of the Rio das Velhas Greenstone Belt, Quadrilátero Ferrífero, Brazil: Influence of Proterozoic Orogenies on Its Western Archean Gold Deposits. Minerals, 10, 983.

Dorr II J.V.N. 1969. Physiographic, Stratigraphic and Structural Development of the Quadrilátero Ferrífero, 
Minas Gerais, Brazil, vol. 641-A. United States Geological Survey/ Departamento Nacional de Produção Mineral, Washington Professional Paper, $110 \mathrm{p}$.

Endo I., Oliveira A. H., Peres G. G., Guimarães M. L. V., Lagoeiro L. E., Machado R., Zavaglia. G., Rosas C. F. Melo R. J. 2005. Nappe Curral: Uma megaestrutura alóctone do Quadrilátero Ferrífero e controle da mineralização. X Simpósio Nacional de Estudos Tectônicos, Curitiba. 279-282.

Endo I., Galbiatti H. F., Delgado C. E. R., Oliveira M. M. F. de, Zapparoli A. de C., Moura L . G. B. de, Peres G. G., Oliveira A. H. de, Zavaglia G., Danderfer $F^{\circ}$ A., Gomes C. J . S ., Carneiro M. A., Nalini Jr. H. A., Castro $P$ de T. A., Suita M. T. de F., S eixas L . A. R ., Tazava E., Lana C. de C., Martins-Neto M. A., Martins M. de S ., Ferreira Fo F. A., Franco A. P., Almeida L . G., Rossi D. Q., Angeli G., Madeira T. J . A., Piassa L . R . A., Mariano D. F., Carlos D. U. 2019. Mapa geológico do Quadrilátero Ferrífero, Minas Gerais, Brasil. Escala 1:150.000. Ouro Preto, Departamento de Geologia, Escola de Minas UFOP - Centro de Estudos Avançados do Quadrilátero Ferrífero: www.gfe2050.ufop.br

Pomerene J.B. 1964. Geology and Ore Deposits of the Belo Horizonte, Ibirite and Macacos Quadrangles, Minas Gerais, Brazil. U.S. Geol. SUN. Prof. Pap., 341- D: I-84.

Ramotoroko C.D., Ranganai R.T., Nyabeze P. 2016. Extension of the Archaean Madibe-Kraaipan granitegreenstone terrane in southeast Botswana: Constrains from gravity and magnetic data. Journal of African Earth Sciences, 123, 39-56.
Ranganai R.T. 2012. Gravity and Aeromagnetic Studies of the Filabusi Greenstone Belt, Zimbabwe Craton: Regional and Geotectonic Implications. International Journal of Geosciences, 3, 1048-1064.

Silva M.A., Cavalcanti, J.A.D., Araújo J.C.S., Ferreira R.C.R., Freitas F.M. 2020. Mapa geológico e de recursos minerais: Quadrilátero Ferrífero - Subárea Central. Escala 1:75.000. Belo Horizonte, CPRM. Available on line at: http://rigeo.cprm.gov.br/handle/doc/20490 (accessed on 16 September 2020)

Talwani M., Worzel J. L., Landisman M., 1959. Rapid gravity computations for two-dimensional bodies with application to the Mendocino submarine fracture zone. Journal of geophysical research, vol. 64, p. 49.

Talwani M., 1964. Computation of magnetic anomalies caused by two-dimensional bodies of arbitrary shape. Computers in the mineral industries, vol. 1, p. 464.

Teixeira, W., Sabate, P., Barbosa, J., Noce, C.M., Carneiro, M.A., 2000. Archean and paleoproterzoic tectonic evolution of the Sao Francisco craton, Brazil. In: Cordani, U.G., Milani, E.J., Thomaz Fo, A., Campos, D.A. (Eds.), Tectonic Evolution of South America, pp. 101-137 Rio de Janeiro.

Zucchetti, M., Baltazar, O.F. 2000. Projeto Rio das Velhas - Texto explicativo do mapa geológico integrado, escala 1:100.000. 2nd ed. Departamento Nacional da Produção Mineral/Companhia de Pesquisa de Recursos Minerais, Belo Horizonte, Brazil, $121 \mathrm{p}$. 